\title{
ANALISIS KESIAPAN MENGHADAPI AKREDITASI PADA PELAYANAN ADMINISTRASI DAN MANAJEMEN DI RUMAH SAKIT UMUM RAJAWALI CITRA KABUPATEN BANTUL (TELAAH PEMBANDING PADA AKREDITASI RUMAH SAKIT
BIDANG PELAYANAN K3B)
}

\author{
Widodo Hariyono \\ Program Studi Ilmu Kesehatan Masyarakat, Fakultas Kesehatan Masyarakat \\ Universitas Ahmad Dahlan \\ widodohariyono@yahoo.com
}

\begin{abstract}
ABSTRAK
Akreditasi rumah sakit bidang pelayanan Keselamatan Kerja, Kebakaran, dan Kewaspadaan Bencana (K3B), dalam persiapannya lebih sulit, daripada bidang pelayanan yang lain, sebab aspek yang dikerjakan sangat kompleks. Di Indonesia, kesiapan sumberdaya manusia, fasilitas, dan dokumentasi yang dimiliki berbagai rumah sakit, belum memadai, sehingga menjadi beban kerja bagi para staf rumah sakit. Bardasarkan pengalaman sebagai pelatih dan konsultan Keselamatan dan Kesehatan Kerja (K3) rumah sakit, persiapan akreditasi pada beberapa rumah sakit di Indonesia tidak standar, baik pada "proses dan objektifitas hasil" dalam akreditasi bidang pelayanan K3B. Kelulusan akreditasi K3B baru sebatas syarat formal bagi rumah sakit.
\end{abstract}

Kata kunci: akreditasi rumah sakit, Keselamatan dan Kesehatan Kerja (K3), persiapan, Indonesia.

\begin{abstract}
Hospital accreditation at Occupational Safety, Burning, and Disaster Alertness (called K3B) field, in its preparation more difficult than another fields, because it have complex aspects. In Indonesia hospitals, preparation at human resources, facilities, and documentation were not adequate, so that became workload to hospital workers. Based to experiences as coach and consultant of hospital Occupational Safety and Health (OSH), accreditation preparation at many hospitals in Indonesia were not standard "in process and result objectivity" for K3B field. The passing of K3B accreditation only limit of formally rules of hospital.
\end{abstract}

Keywords: hospital accreditation, occupational safety and health, preparation, Indonesia.

Berdasarkan pengalaman. Terkait pengalaman saya sebagai pelatih pada pelatihan Keselamatan dan Kesehatan Kerja (K3) rumah sakit, juga sebagai konsultan akreditasi K3 rumah sakit yang telah saya lakukan pada beberapa rumah sakit di Indonesia, saya mencoba mencari artikel yang terkait dengan akreditasi K3 rumah sakit. Beberapa penelitian yang terkait dengan pelaksanaan K3 di rumah sakit telah dihasilkan. ${ }^{1}$ Namun, fokus penelitian yang mencermati persiapan akreditasi K3 rumah sakit, belum saya temukan. Justru saya tertarik dengan tulisan yang dimuat dalam Jurnal Kes Mas, Volume 5, Nomor 2, Juni 2011, halaman 128 - 136. Artikel tersebut ditulis oleh Pawizi dan Rosyidah. ${ }^{2}$ Di dalam tulisan tersebut, dibahas hal yang terkait dengan proses persiapan rumah sakit dalam menghadapi akreditasi bidang pelayanan administrasi dan manajemen, dari tiga segi dan sumberdaya yang mendasar.

Dalam pengalaman riil, saya bukan pelaku dalam akreditasi bidang pelayanan tersebut (sebagai salah satu bidang dalam paket pelayanan dasar berjumlah lima bidang), tetapi saya punya pengalaman dalam akreditasi bidang pelayanan Keselamatan Kerja, Kebakaran, dan Kewaspadaan Bencana (sering disebut sebagai 
K3B). Terkait dengan korespondensi ini, saya akan memberikan bahasan tentang pengalaman saat mengikuti proses akreditasi rumah sakit bidang K3B di beberapa rumah sakit yang menjadi tempat saya memberikan pelatihan K3 (in-house training). Adapun segi dan sumberdaya yang saya bahas, mengikuti formulasi yang ditulis dalam artikel milik Pawizi dan Rosyidah pada judul artikel di atas, dengan memberikan telaah singkat yang sifatnya membandingkan antara dua jenis bidang pelayanan yang saling bertolak belakang tingkat kesulitan dalam penyiapannya. Segi dan sumberdaya mendasar yang dapat disebut sebagai faktor penentu kesiapan akreditasi adalah (1) sumberdaya manusia, (2) fasilitas, dan (3) dokumentasi.

Bidang pelayanan K3B. Bidang tersebut sebagai salah satu bidang dalam paket 12 bidang pelayanan yang diakreditasi oleh Komisi Akreditasi Rumah Sakit (KARS). Salah satu hal yang spesifik menjadi masalah besar dalam persiapan akreditasi bidang pelayanan K3B adalah tingkat kesulitan dan besarnya cakupan materi yang harus dipersiapkan oleh pihak rumah sakit. Dalam paket akreditasi 12 bidang pelayanan, jelas bahwa K3B merupakan bidang yang paling berat dan sulit untuk dapat secara cepat diimplementasikan.

Pada 11 bidang selain K3B, pada umumnya proses jalannya sistem kerja telah berlangsung lama dan dilakukan oleh para staf yang telah memiliki peran dan pengalaman sehari-hari. Bidang-bidang tersebut telah eksis dan dilakukan sebagai proses logis kebutuhan pelayanan bagi semua konsumen di rumah sakit. Namun, bidang K3B bisa disebut sebagai bidang 'baru dan asing' bagi para staf, sebab selama ini tidak pernah ada implementasi yang jelas dan tegas tentang praktik kerja yang memenuhi standar ilmu K3B rumah sakit. Maka, yang terjadi adalah 'pemaksaan' pengusulan bidang pelayanan K3B yang serba sulit, membingungkan, menimbulkan beban psikologis yang berat, rasa gamang, dan stagnan.

Kesiapan sumberdaya manusia. Dari segi ini, bidang K3B paling sulit, sebab masih langkanya ahli K3 yang dimiliki oleh setiap rumah sakit. Para staf yang ditunjuk untuk menyiapkan perangkat akreditasi bidang K3B, juga sebagian besar tidak (belum) memahami ilmu K3, atau terbebani bidang kerja ini. Hal ini sangat kontras dengan bidang pelayanan administrasi dan manajemen yang telah berjalan sejak awal, saat suatu rumah sakit beroperasi. Meskipun mungkin ada kekurangan dalam beberapa aspek, tetapi bidang administrasi dan manajemen dapat cepat disiapkan dan dilengkapi perangkatnya oleh Kelompok Kerja (Pokja) terkait, berbeda dengan bidang $\mathrm{K} 3 \mathrm{~B}$ yang harus menunggu penanganan sistemik dari unsur pimpinan utama rumah sakit sampai staf di bagian teknis operasional terbawah (sumberdaya manusia yang terlibat sangat kompleks profesinya).

Kesiapan fasilitas. Dari segi ini, bidang K3B paling sulit, rumit, dan mahal biayanya, sebab cakupan sistem yang harus disiapkan meliputi seluruh area rumah sakit, dengan cakupan berbagai mesin, peralatan, bahan baku, fasilitas, bangunan, dan area lainnya. Penyiapan ini meliputi pencocokan pada semua standar K3B, yang konsekuensinya harus merubah kondisi yang salah, atau membuat suatu betuk yang baru, dengan biaya yang cukup besar (mahal). Tidak hanya pada unit kerja tertentu, tetapi meliputi semua unit kerja dan area yang terdapat di rumah sakit.

Sampai saat ini, banyak rumah sakit di Indonesia, sistem fisiknya dibuat tanpa aturan dan parameter khusus yang terkait $\mathrm{K} 3 \mathrm{~B}$, sehingga dengan adanya akreditasi bidang ini, penyiapan infrastruktur dan ruang lingkup sistem fisiknya lebih banyak merubah kondisi yang salah (re-desain). Sebagai contoh, jika aturan dan parameter ruang dan bangunan harus mengacu pada standar internasional yang dibuat di Amerika Serikat, tentunya menjadi sangat berat bagi banyak rumah sakit di Indonesia. ${ }^{3}$ $\mathrm{Hal}$ ini tentu memerlukan ilmu yang memadai dan biaya yang besar. Kontras sekali dengan bidang pelayanan administrasi dan manajemen yang disiapkan dalam sistema dokumentasi yang bersifat software, berbeda dengan bidang K3B yang harus melakukan penanganan fisik dan lebih banyak bersifat hardware. 
Kesiapan dokumentasi. Dari segi ini bidang K3B paling sulit dan berat, bukan pada anggaran pencetakan dokumennya yang sangat banyak, tetap pada ide dan penguasaan ilmu K3B yang dimiliki oleh para staf rumah sakit dalam Pokja ini. Bisa dikatakan, bahwa konten ilmu K3, baik secara teori maupun praktik, tidak banyak dimiliki oleh para staf di rumah sakit. IImu ini dianggap baru, tidak tersosialisasi sejak awal saat para staf bekerja di rumah sakit, dan bisa dikatakan muncul secara tiba-tiba saat harus menghadapi akreditasi bidang K3B. Padahal, K3B adalah suatu ilmu yang penguasaannya akan kuat dan mapan seiring dengan berjalannya waktu pada sesorang yang memraktikkannya sehari-hari.

Terkait dengan hal tersebut, ketika program penyusunan dokumen K3B dilakukan (mulai dari dokumen kebijakan, peraturan, petunjuk pelaksanaan, petunjuk teknis atau Prosedur Operasional Standar/POS), maka yang terjadi adalah kebingungan dan kegamangan psikologis pada para staf. Pernah dalam suatu proyek konsultasi penyusunan dokumen akreditasi bidang K3B, setelah waktu dua pekan saya berikan penugasan membuat dokumen kepada para staf di Pokja K3B, mereka sama sekali tidak mengerjakan tugas yang saya berikan tersebut. Jawaban mereka atas pertanyaan saya adalah, bahwa mereka bingung, ragu, dan gamang untuk membuat suatu dokumen K3B yang isinya belum mereka kuasai secara matang (padahal mereka sudah dilatih K3B selama tiga hari, sebelum menyusun dokumen).

$\mathrm{Hal}$ ini sangat kontras dengan bidang pelayanan administrasi dan manajemen yang telah berjalan sejak awal mula suatu rumah sakit beroperasi. Meskipun mungkin ada kekurangan dalam beberapa aspek, tetapi bidang administrasi dan manajemen telah dikuasai dengan praktik sehari-hari dalam penanganan dokumen maupun bekerja sesuai dengan deskripsi tugas setiap stafnya (pola hirarki organisasi). Berbeda dengan bidang K3B yang harus belajar dan dilatih dulu secara khusus, kemudian menerapkannya secara bertahap dan lalu menuliskannya menjadi dokumen (misalnya POS atau instruksi kerja).

Kesiapan dalam menghadapi akreditasi. Dalam simpulan penelitiannya, Pawizi dan Rosyidah menyimpulkan bahwa dari aspek sumberdaya manusia, fasilitas, dan dokumentasi yang disiapkan dalam menghadapi akreditasi bidang pelayanan administrasi dan manajemen di rumah sakit tersebut, semuanya dalam kondisi siap dan baik. Artinya, tidak ada kendala berarti yang terkait dengan penyiapan 3 segi dan sumberdaya mendasar. Secara teoritis, bidang pelayanan ini tidak berat untuk disiapkan sebagai salah satu dari lima bidang pelayanan dalam paket dasar akreditasi rumah sakit. Namun, di sisi lain, bidang pelayanan K3B yang merupakan paket kedua (salah satu dari 12 bidang pelayanan) akreditasi rumah sakit, menjadi beban cukup berat bagi penyiapannya. Merujuk pada tulisan Hariyono, salah satu hal terpenting yang menjadi alasan beratnya implementasi K3 di rumah sakit adalah ketiadaan unit kerja mandiri yang mengurusi secara tetap masalah $\mathrm{K} 3$ di setiap rumah sakit. ${ }^{4}$

Sebagai penutup, sesuai pengalaman saya, fakta riil di lapangan (rumah sakit) terkait dengan persiapan akreditasi rumah sakit bidang pelayanan $\mathrm{K} 3 \mathrm{~B}$, yang terjadi adalah (1) adanya praktik manipulasi dokumen akreditasi yang disiapkan oleh rumah sakit, (2) adanya persiapan asal-asalan, baik segi software maupun hardware, untuk untung-untungan mendapatkan nilai baik/lulus, (3) adanya ketidaksiapan personil dalam memahami K3, dan sikap tidak konsisten pada sumberdaya manusia rumah sakit, bahwa yang penting bisa lulus akreditasi, tetapi pelaksanaan K3 secara riil, itu perkara lain, (4) adanya ketidaksiapan anggaran menjadi kendala pada ketidakmampuan rumah sakit untuk siap diakreditasi. Bidang pelayanan K3B memang masih menjadi bidang terberat dalam akreditasi rumah sakit di Indonesia sampai saat ini. 


\section{DAFTAR PUSTAKA}

1. Sambudi, D., Sutomo, A.H., Hariyono, W. Pelaksanaan Keselamatan dan Kesehatan Kerja di Rumah Sakit Umum Daerah Bangkinang. Working Paper Series, Nomor 4, April 2007, First Draft. Program Magister KMPK, Universitas Gadjah Mada, Yogyakarta, 2006. Diakses dari: http://id.scribd.com/doc/45176785/no-4dedy-sambudi-04-07. Tanggal: 1 Januari 2014.

2. Pawizi dan Rosyidah. Analisis Kesiapan Menghadapi Akreditasi Pada Pelayanan Administrasi dan Manajemen di Rumah Sakit Umum Rajawali Citra Kabupaten Bantul, Jurnal Kes Mas. Volume 5, Nomor 2, Juni 2011: 128 - 136.

3. Kobus, R.L., Skaggs, R.L., Bobrow, M., Thomas, J., and Payette, T.M. Building Type Basics for Healthcare Facilities. John Wiley \& Sons, Inc., New York, 2000.

4. Hariyono, W. The Concept of Establishing Autonomous Occupational Safety and Health in Hospitals: an Abstraction Proposal, Journal of Human Ergology. Volume 36, Number 2, December 2007: 69 - 74. 